\title{
Desempeño a temperaturas altas de morteros y hormigones basados en mezclas de escoria/metacaolín activadas alcalinamente
}

\section{High-temperature performance of mortars and concretes based on alkali-activated slag/metakaolin blends}

\author{
S. A. Bernal(*,**), R. Mejía de Gutiérrez(*), F. Ruiz(*), H. Quiñones(*), J. L. Provis(**)
}

Recepción/Received: 23-IV-12

Aceptación/Accepted: 3-VII-12

\section{RESUMEN}

Este artículo evalúa el desempeño de morteros y hormigones basados en mezclas de escoria siderúrgica (GBFS)/metacaolín (MK), activadas alcalinamente expuestos a temperaturas altas. Se identifica una elevada estabilidad en morteros con contenidos de MK de hasta un $60 \%$ cuando se exponen a temperaturas de $600{ }^{\circ} \mathrm{C}$, con una resistencia residual de 20 MPa posterior a la exposición a esta temperatura. Por otra parte, la exposición a temperaturas más elevadas conduce al agrietamiento de los hormigones como consecuencia de una elevada contracción de la matriz cementante y las restricciones por efecto de los áridos, especialmente en aquellos especímenes con cementantes que contienen altos contenidos de MK. Se identifican diferencias significativas en las propiedades de absorción de agua de morteros y hormigones, y esto se relaciona con las divergencias en el desempeño de estos materiales posterior a la exposición a temperaturas altas. Esto indica que el desempeño a temperaturas elevadas de morteros de activación alcalina no es completamente transferible a hormigones, ya que los sistemas difieren en permeabilidad. Las diferencias en los coeficientes de expansión térmica entre matriz cementante y los áridos gruesos contribuyen al macrofisuramiento del material y su consecuente reducción de propiedades mecánicas.

Palabras claves: cementos alcalinos, altas temperaturas, escoria siderúrgica, metacaolín, propiedades mecánicas.

\section{SUMMARY}

This paper assesses the performance of mortars and concretes based on alkali activated granulated blastfurnace slag (GBFS)/metakaolin (MK) blends when exposed to high temperatures. High stability of mortars with contents of MK up to 60 wt.\% when exposed to $600{ }^{\circ} \mathrm{C}$ is identified, with residual strengths of $20 \mathrm{MPa}$ following exposure to this temperature. On the other hand, exposure to higher temperatures leads to cracking of the concretes, as a consequence of the high shrinkage of the binder matrix and the restraining effects of the aggregate, especially in those specimens with binders containing high $M K$ content. A significant difference is identified between the water absorption properties of mortars and concretes, and this is able to be correlated with divergences in their performance after exposure to high temperatures. This indicates that the performance at high temperatures of alkali-activated mortars is not completely transferable to concrete, because the systems differ in permeability. The differences in the thermal expansion coefficients between the binder matrix and the coarse aggregates contribute to the macrocracking of the material, and the consequent reduction of mechanical properties.

Keywords: alkali-activated binders, high temperatures, granulated blast-furnace slag, metakaolin, mechanical properties.

\footnotetext{
(*) Universidad del Valle, Cali (Colombia).

(**) University of Melbourne, Victoria (Australia).
} 


\section{INTRODUCCIÓN}

Ante la necesidad de minimizar el impacto medio ambiental asociado con la producción de cemento Portland y atender los requerimientos constructivos de estructuras modernas de resistencia mecánica y durabilidad, ha adquirido cada vez mayor importancia el desarrollo de cementantes alternativos, entre estos los denominados cementos alcalinos $(1,2)$ los cuales se han clasificado en dos grandes grupos: sistemas basados en $(\mathrm{Na}, \mathrm{K})_{2} \mathrm{O}-$ $\mathrm{CaO}-\mathrm{Al}_{2} \mathrm{O}_{3}-\mathrm{SiO}_{2}-\mathrm{H}_{2} \mathrm{O}$, donde se encuentran los cementos de escoria activada alcalinamente, y los sistemas basados en $(\mathrm{Na}, \mathrm{K})_{2} \mathrm{O}-\mathrm{Al}_{2} \mathrm{O}_{3}-\mathrm{SiO}_{2}-\mathrm{H}_{2} \mathrm{O}$, conocidos como geopolímeros, siendo estos últimos producidos a partir de precursores de tipo aluminosilicato con bajo o ningún contenido de calcio tales como cenizas volantes clase $\mathrm{F}$ o metacaolín (3). La principal diferencia entre estas dos clases de cementantes es la presencia de calcio en la escoria lo que promueve la formación de una estructura compuesta fundamentalmente por geles de silicatos cálcicos hidratados (C-(A)-S-H) (2), mientras que en los geopolímeros se forman geles del tipo aluminosilicato sódico hidratado (N-A-S-H) (4).

El uso tanto de metacaolín como de escoria activada alcalinamente para la producción de materiales cementantes ha sido ampliamente estudiado en las últimas décadas (4-7). Sin embargo, hay aún muchas interrogantes respecto de su desempeño y estabilidad cuando son expuestos a medios agresivos, siendo esto una de las principales limitantes para su estandarización y comercialización (8). Estudios de materiales de activación alcalina elaborados con metacaolín (9-14) o escoria siderúrgica (15-19) han mostrado, que independientemente del precursor usado, generalmente estos cementantes reportan una mejorada estabilidad cuando son expuestos a temperaturas altas, comparado con el cemento Portland ordinario. Esto es más significativo en cementos alcalinos con bajos o ningún contenido de calcio, lo cual se atribuye a la formación de un gel cementante altamente polimerizado del tipo aluminosilicato sódico hidratado (4) y un contenido reducido de agua químicamente enlazada en los productos de reacción (20).

En mezclas cementantes de metacaolín y escoria activadas alcalinamente se ha identificado un mayor control en los tiempos de fraguado (21), mayor estabilidad dimensional del material (reducida contracción por secado) y el desarrollo de buenas propiedades mecánicas, cuando estos son formulados adecuadamente, y se comparan con los resultados obtenidos cuando cada uno de los precursores es activado de manera individual (11). Esto es consecuencia de la modificación de la estructura del gel geopolimérico en matrices de metacaolín activado alcalinamente, con la

\section{INTRODUCTION}

Given the need to minimise the environmental impact associated with the production of Portland cement, and addressing the requirements of modern structural engineering in terms of mechanical strength and durability, the development of alternative cements has become more important. Among these are the materials referred to as alkali-activated cements $(1,2)$, which have been classified in two groups: systems based on $(\mathrm{Na}, \mathrm{K})_{2} \mathrm{O}-\mathrm{CaO}-\mathrm{Al}_{2} \mathrm{O}_{3}-\mathrm{SiO}_{2}-\mathrm{H}_{2} \mathrm{O}$, including alkali-activated slag binders, and systems based on $(\mathrm{Na}, \mathrm{K})_{2} \mathrm{O}-\mathrm{Al}_{2} \mathrm{O}_{3}-$ $\mathrm{SiO}_{2}-\mathrm{H}_{2} \mathrm{O}$ referred to as geopolymers, the latter being produced from aluminosilicate type precursors with low or no calcium content, such as class F fly ash or metakaolin (3). The main differences between those classes of binders is the presence of calcium, which promotes the formation of a structure fundamentally composed of calcium silicate hydrate type gels (C- $(A)-S$ $H(2)$, while in geopolymers an aluminosilicate type gel $(N-A-S-H)$ is formed (4).

The use of metakaolin-based geopolymers and alkaliactivated slags for the production of cementitious materials has been studied extensively in the past decades (4-7). However, there are still questions regarding the performance and stability of these materials when exposed to aggressive service environments, and this is one of the main limitations facing standardisation and commercialisation of alkaliactivated materials(8). Studies of alkali-activated materials based on metakaolin (9-14) or slag (15-19) have shown that independent of the precursor used, alkaliactivated cements generally show greater stability when exposed to high temperatures, compared with ordinary Portland cement. This is more remarkable in alkaliactivated cements with low calcium contents, which is attributed to the formation of a highly crosslinked sodium aluminosilicate type gel (4), and a reduced content of chemically-bonded water in the reaction products (20).

In alkali-activated blended binders based on metakaolin and slag, better control of the setting times (21), improved dimensional stability of the material (reduced drying shrinkage) and the development of good mechanical properties (when adequately formulated) have been observed, compared with the results obtained when each precursor is individually activated (11). This is a consequence of the modification of the geopolymer gel structure in alkali-activated metakaolin matrices through the inclusion of slag. The structural analysis of alkali-activated metakaolin/slag pastes exposed to high 
inclusión de escoria. El análisis estructural de pastas de metacaolín/escoria activadas alcalinamente expuestas a temperaturas elevadas revela (11) que la inclusión de un $20 \%$ de escoria favorece una mayor retención de la resistencia mecánica; sin embargo, la densificación que ocurre en materiales basados únicamente en metacaolín a temperaturas entre $800^{\circ} \mathrm{C}$ y $1.000{ }^{\circ} \mathrm{C}$ no tiene lugar cuando se incorpora calcio en el sistema, como consecuencia de la formación simultanea de los geles cementantes tipo C-S-H y de aluminosilicato. Esto reduce la severa contracción que sufre el material cuando se expone a estas temperaturas, presentando una mayor estabilidad dimensional posterior a la exposición a temperaturas elevadas.

El comportamiento a elevadas temperaturas de hormigones, sean basados en cemento Portland o en cementos alcalinos, es principalmente dominado por la expansión térmica de los áridos, ya que los áridos conforman entre el 65 al $80 \%$ del volumen total del hormigón (22). Van Riessen y Rickard (23) han reportado que durante la exposición a temperaturas elevadas de hormigones la matriz cementante se contrae, mientras que los áridos finos y gruesos se expanden lo que tiene implicaciones significativas en la estabilidad dimensional del material y en su desempeño mecánico posterior a la exposición a altas temperaturas. A la fecha no se encuentran estudios del comportamiento de morteros y hormigones elaborados con cementantes alcalinos basados en mezclas cementantes de una escoria y un metacaolín, donde la incorporación de áridos puede modificar el comportamiento del material.

En el presente estudio se evalúa el desempeño frente a altas temperaturas de morteros y hormigones basados en mezclas cementantes de una escoria siderúrgica de alto horno y un metacaolín activados alcalinamente. Específicamente se determina la pérdida en peso, la pérdida de resistencia a la compresión, y el volumen de poros permeables de todas las muestras en estudio, cuando se exponen a temperaturas de hasta $1.000^{\circ} \mathrm{C}$

\section{PROGRAMA EXPERIMENTAL}

\subsection{Materiales}

Como materia primaria para la elaboración de los productos cementantes se empleó una escoria siderúrgica de alto horno colombiana y un metacaolín producido en el laboratorio a partir de la calcinación de un caolín de alta pureza a $700{ }^{\circ} \mathrm{C}$ en una atmósfera de aire. La composición química de estos materiales fue determinada a través de fluorescencia de rayos $X, y$ se presenta en la Tabla 1. temperatures reveals (11) that the inclusion of $20 \mathrm{wt} \%$ slag favours the retention of higher mechanical strengths; however, the densification observed in geopolymers solely based on metakaolin at temperatures between $800^{\circ} \mathrm{C}$ and $1000^{\circ} \mathrm{C}$ does not take place with the incorporation of calcium in the system, as a consequence of the simultaneous formation of the $\mathrm{C}-\mathrm{S}-\mathrm{H}$ and aluminosilicate binding gels. The coexistence of the two types of gels leads to reduced shrinkage when the material is exposed to high temperatures, and therefore better thermal dimensional stability.

The performance of concretes at elevated temperatures, whether based on ordinary Portland cement or alkaliactivated cements, is also dominated by the thermal expansion of the aggregates, as the aggregates constitute $65-85 \%$ of the total volume of the concrete (22).Van Riessen and Rickard (23) have reported that during high temperature exposure of alkali-activated materials the binding matrix shrinks, while the fine and coarse aggregates expand, which will have significant consequences for the dimensional stability of the material, and in the mechanical performance after exposure. To date, there are no reports in the literature regarding the performance of mortars and concretes prepared with alkali-activated binders based on blends of slag and metakaolin when exposed to high temperatures, where the incorporation of aggregates might modify the material performance.

In the present study the performance at high temperatures of mortars and concretes based on alkaliactivated binary blends of slag and metakaolin is assessed. Specifically, weight loss, compressive strength loss and the volume of permeable pores of the samples are determined following exposure to temperatures of up to $1000^{\circ} \mathrm{C}$

\section{EXPERIMENTAL PROGRAM}

\subsection{Materials}

As raw materials for the production of the binders, a Colombian granulated blast furnace slag, and a metakaolin produced in the laboratory through the calcination of high purity kaolin at $700^{\circ} \mathrm{C}$ in air, were used. The chemical compositions of the materials as determined through $X$-ray fluorescence are shown in Table 1. 
Tabla 1 / Table 1

Composición química de la escoria siderúrgica y el metacaolín. Chemical composition of slag and metakaolin.

\begin{tabular}{|c|c|c|}
\hline Componente \% en peso / Component wt. \% & Escoria / Slag & Metacaolín / Metakaolin \\
\hline $\mathrm{SiO}_{2}$ & 32.29 & 50.72 \\
\hline $\mathrm{Al}_{2} \mathrm{O}_{3}$ & 16.25 & 44.63 \\
\hline $\mathrm{CaO}$ & 42.45 & 2.69 \\
\hline $\mathrm{Fe}_{2} \mathrm{O}_{3}$ & 2.35 & - \\
\hline $\mathrm{MgO}$ & 2.87 & - \\
\hline Otros / Others & 1.88 & 0.94 \\
\hline Pérdida al fuego / Loss on ignition, $1000^{\circ} \mathrm{C}$ & 1.91 & 1.02 \\
\hline
\end{tabular}

A partir de la composición química de la escoria (Tabla 1) se determinó que este material presenta un coeficiente de basicidad $\left(\mathrm{M}_{\mathrm{b}}=(\mathrm{CaO}+\mathrm{MgO}) /\left(\mathrm{SiO}_{2}+\mathrm{Al}_{2} \mathrm{O}_{3}\right)\right)$ de 0,93 y un coeficiente de calidad $\left(\left(\mathrm{CaO}+\mathrm{MgO}+\mathrm{Al}_{2} \mathrm{O}_{3}\right) /\right.$ $\left(\mathrm{SiO}_{2}+\mathrm{TiO}_{2}\right)$ de 1,90 , lo cual indica que la naturaleza de la escoria es aproximadamente neutra. Las propiedades físicas de la escoria y el metacaolín se resumen en la Tabla 2.

Como disolución activadora se emplearon mezclas de un silicato de sodio comercial de composición 32,4\% $\mathrm{SiO}_{2}$, $13,5 \% \mathrm{Na}_{2} \mathrm{O}$ y $54,1 \% \mathrm{H}_{2} \mathrm{O}$, y un $\mathrm{NaOH}$ comercial al $50 \%$. La dosificación de los activadores alcalinos se llevó a cabo de manera que se obtuvieran relaciones de óxidos totales específicas.

Para la elaboración de los hormigones de alto desempeño se emplearon dos tipos de arenas de río de tipo silíceo con una gravedad especifica de $2.450 \mathrm{~kg} / \mathrm{m}^{3}$ (árido fino 1) y $2.720 \mathrm{~kg} / \mathrm{m}^{3}$ (árido fino 2), y módulo de finura de 2,75 y 3,21 , respectivamente. Como árido grueso se empleó una grava de tipo silíceo con tamaño máximo de $19 \mathrm{~mm}$, gravedad específica de $3000 \mathrm{~kg} / \mathrm{m}^{3}$ y absorción de $0,81 \%$. La granulometría de estos materiales se presenta en la Tabla 3.

\subsection{Diseño de mezclas y preparación de especímenes}

Las morteros de activación alcalina fueron dosificados con una relación escoria/ (escoria + metacaolin) de 1.0 ( $100 \%$ escoria), $0,8,0,6,0,4$ y 0,2 (20\% escoria/ $80 \%$ metacaolín), y una relación cementante:arena (árido fino 1)
Based on the chemical composition of the slag (Table 1), the basicity coefficient $\left(\mathrm{M}_{b}=(\mathrm{CaO}+\mathrm{MgO}) /\right.$ $\left.\left(\mathrm{SiO}_{2}+\mathrm{Al}_{2} \mathrm{O}_{3}\right)\right)$ was 0.93 and the quality coefficient $\left(\left(\mathrm{CaO}+\mathrm{MgO}+\mathrm{Al}_{2} \mathrm{O}_{3}\right) /\left(\mathrm{SiO}_{2}+\mathrm{TiO}_{2}\right)\right.$ was 1.90 , which indicates that this is a neutral slag. The physical properties of the slag and metakaolin are summarised in Table 2.

As activating solutions, blends of a commercial sodium silicate solution (32.4 wt. \% $\mathrm{SiO}_{2}, 13.5$ wt. $\% \mathrm{Na}_{2} \mathrm{O}$ and 54.1 wt. $\% \mathrm{H}_{2} \mathrm{O}$ ), and 50 wt. $\% \mathrm{NaOH}$ solution, were used. The activators were formulated to reach specified desired overall molar ratios.

Two types of siliceous river sand were used for the production of the concretes, having specific gravity of $2450 \mathrm{~kg} / \mathrm{m}^{3}$ (fine aggregate 1) and $2720 \mathrm{~kg} / \mathrm{m}^{3}$ (fine aggregate 2), and fineness moduli of 2.75 and 3.21, respectively. As coarse aggregate, siliceous gravel with a maximum size of $19 \mathrm{~mm}$, specific gravity of $3000 \mathrm{~kg} / \mathrm{m}^{3}$ and absorption of $0.81 \%$ was used. The particle size distributions of these materials are shown in Table 3.

\subsection{Mix design and specimen preparation}

Alkali-activated mortars were formulated with slag/(slag+metakaolin) ratios of 1.0 (100 wt.\% slag), $0.8, \quad 0.6,0.4$ and 0.2 (20 wt. $\%$ slag/80 wt. $\%$ metakaolin), and a binder:sand (fine aggregate 1 ) ratio

Tabla 2 / Table 2

Propiedades físicas de la escoria siderúrgica y el metacaolín.

Physical properties of slag and metakaolin.

\begin{tabular}{|c|c|c|}
\hline Propiedad / Property & Escoria / Slag & Metacaolín / Metakaolin \\
\hline Gravedad específica / Specific gravity, $\mathrm{kg} / \mathrm{m}^{3}$ & 3000 & 2500 \\
\hline Superficie específica Blaine / Blaine specific surface, $\mathrm{m}^{2} / \mathrm{kg}$ & 498 & 391 \\
\hline
\end{tabular}


Tabla 3 / Table 3

Distribución granulométrica de los áridos.

Granulometric distribution of the aggregates.

\begin{tabular}{|c|c|c|c|}
\hline \multirow{2}{*}{ Tamiz /Sieve size ( $\boldsymbol{N}^{\circ}$ ) } & \multicolumn{3}{|c|}{ Porcentaje retenido acumulado / Cumulative percentage retained } \\
\cline { 2 - 4 } & Árido grueso / Coarse aggregate & Árido fino 1 / Fine aggregate 1 & Árido fino 2 / Fine aggregate 2 \\
\hline $25 \mathrm{~mm}(1 \mathrm{in})$ & 0 & - & - \\
\hline $19 \mathrm{~mm}(3 / 4 \mathrm{in})$ & 1.86 & - & - \\
\hline $12.5(1 / 2 \mathrm{in})$ & 21.86 & - & 0 \\
\hline $9.5 \mathrm{~mm} \mathrm{(3/8} \mathrm{in)}$ & 57.71 & 0 & 1.22 \\
\hline $4.75 \mathrm{~mm}(4)$ & 97.39 & 5.64 & 23.77 \\
\hline $2.36 \mathrm{~mm}(8)$ & 100 & 13.59 & 40.20 \\
\hline $1.18 \mathrm{~mm}(16)$ & 100 & 27.43 & 59.78 \\
\hline $600 \mu \mathrm{m} \mathrm{(30)}$ & 100 & 48.03 & 87.36 \\
\hline $300 \mu \mathrm{m}(50)$ & 100 & 81.52 & 98.64 \\
\hline $150 \mu \mathrm{m} \mathrm{(100)}$ & 100 & 98.67 & \\
\hline
\end{tabular}

de $1: 2.75$. El activador alcalino fue dosificado de manera que se obtuvieran relaciones molares totales de los óxidos $\mathrm{SiO}_{2} / \mathrm{Al}_{2} \mathrm{O}_{3}$ de 4,0 y una relación constante $\mathrm{Na}_{2} \mathrm{O} / \mathrm{SiO}_{2}$ de 0,25 . Es importante mencionar que estas relaciones molares no tienen en consideración la probabilidad de la reacción incompleta de los precursores sólidos, y por lo tanto no debe ser considerado como una representación de la composición molar de los geles cementantes; estas relaciones son especificadas para propósitos de diseño. Los morteros fueron elaborados con una relación agua/ (escoria + metacaolín + activador anhidro) de 0,6. La equivalencia entre las concentraciones de la disolución activadora (expresada como $\% \mathrm{Na}_{2} \mathrm{O}$ respecto de la cantidad de escoria+metacaolín a activar) y la relación de óxidos molares utilizada en este estudio como criterio de activación ha sido reportada en (24). Estas condiciones de activación han sido identificadas como adecuadas para la producción de cementantes de activación alcalina con altos contenidos de metacaolín, con una aceptable trabajabilidad en pastas (25).

Los morteros fueron producidos de acuerdo con el procedimiento estándar ASTM C 305, colocados en moldes cúbicos de 50,8 mm de arista. Las muestras en estado fresco fueron puestas en una mesa vibradora durante un minuto para disminuir el contenido de aire atrapado que pudiese estar presente, especialmente en aquellos morteros con contenidos más elevados de metacaolín cuya consistencia fue bastante pegajosa. Los morteros fueron curados dentro de los moldes en una cámara húmeda a temperatura ambiente $\left(\mathrm{T}=25^{\circ} \mathrm{C}\right)$ durante $24 \mathrm{~h}$. Posteriormente, las muestras fueron demoldeadas y curadas bajo condiciones de humedad relativa $(H R)>90 \%$ a una temperatura de $27 \pm 2{ }^{\circ} \mathrm{C}$ hasta la edad de ensayo.

Los hormigones fueron diseñados de acuerdo a lo especificado en la norma ACI 211, con un contenido de of 1:2.75. The alkaline activators were dosed in order to reach an overall (activator + solid precursor) $\mathrm{SiO}_{2} / \mathrm{Al}_{2} \mathrm{O}_{3}$ (S/A) molar ratio of 4.0 , and a constant $\mathrm{Na}_{2} \mathrm{O} / \mathrm{SiO}_{2}$ molar ratio of 0.25 . It is noted that the overall molar ratios do not account for the strong probability of incomplete reaction of the solid precursors, and thus should not be taken as being representative of the molar composition of the binder gel; the ratios are specified for mix design purposes. The mortars were produced with a water/(slag + metakaolin + anhydrous activator) ratio of 0.6 . The equivalence between the concentration of the activating solution (expressed as wt. $\% \mathrm{Na}_{2} \mathrm{O}$ relative to the amount of slag+metakaolin to be activated) and the overall oxide ratios used in this study as formulation criteria has been reported in (24). These formulation conditions have been identified as adequate for the production of alkaliactivated binders with high metakaolin contents, with acceptable workability (25).

Mortars were produced in accordance with the standard test method ASTM C 305, and cast in $50.8 \mathrm{~mm}$ cubic moulds. The fresh samples were vibrated for 1 min to reduce the content of trapped air, especially in those mortars with high contents of metakaolin which exhibited a sticky consistency. Specimens were cured in the moulds in a humidity chamber $(>98 \%$ relative humidity) at $25^{\circ} \mathrm{C}$ for $24 \mathrm{~h}$. Afterwards, the samples were demoulded and cured at a relative humidity $>90 \%$ and a temperature of $27 \pm 2{ }^{\circ} \mathrm{C}$.

Concretes were designed in accordance with the ACI 211 standard, with a binder (slag+metakaolin) content of 
cementante (escoria +metacaolín) por metro cúbico de hormigón de $400 \mathrm{~kg}$. Esta cantidad de cementante fue seleccionada a partir de los resultados de estudios previos $(24,26)$. Únicamente se elaboraron hormigones con relaciones de escoria/ (escoria + metacaolín) de 1,0 (100\% escoria) y 0,4 (40\% escoria/ $60 \%$ metacaolín), y relación agua/(escoria + metacaolín + activador anhidro) de 0,6. En ningún caso se incorporaron aditivos a las mezclas frescas, las cuales fueron moldeadas en cilindros de $76,2 \mathrm{~mm}$ de diámetro y $152,4 \mathrm{~mm}$ de altura.

\subsection{Ensayos realizados}

En las muestras de mortero, se determinó la resistencia a la compresión de acuerdo a la normativa ASTM C109 a edades de curado de 7, 28 y 60 días. Las propiedades mecánicas de los hormigones fueron evaluadas a edades de curado de 7 y 28 días, así: la resistencia a la compresión fue determinada de acuerdo al procedimiento estándar ASTM C39, la resistencia a la tracción indirecta de acuerdo a la normativa ASTM C496, y la resistencia a la flexión evaluada en vigas con dimensiones son 102 × 102 × 274 mm, de acuerdo al método de tres puntos descrito en la normativa ASTM C78. El volumen de poros permeables de estos especímenes fue obtenido de acuerdo a la normativa ASTM C642. De acuerdo a esta normativa los especímenes son secados a $100^{\circ} \mathrm{C}$ hasta alcanzar peso constante. Posteriormente las muestras son sumergidas en agua durante $48 \mathrm{~h}$ para determinar el peso seco saturado. Una vez hecho esto las muestras son hervidas a $100^{\circ} \mathrm{C}$ durante $5 \mathrm{~h}$ y se determina el peso seco saturado después de hervido, y el peso aparente de las muestras sumergidas en agua usando una balanza hidrostática.

\subsection{Exposición a altas temperaturas}

El estudio del comportamiento frente a elevadas temperaturas fue llevado a cabo usando muestras de mortero y hormigón, posterior a 28 días de curado. En el caso de los morteros, estos fueron expuestos a $200^{\circ} \mathrm{C}$ y $600^{\circ} \mathrm{C}$ durante dos horas, utilizando una velocidad de calentamiento de $10^{\circ} \mathrm{C} / \mathrm{min}$ hasta alcanzar la temperatura de exposición deseada, seguido ello por un enfriamiento lento dentro del horno. Los hormigones fueron sometidos a temperaturas de $200^{\circ} \mathrm{C}, 400^{\circ} \mathrm{C}, 600^{\circ} \mathrm{C}, 800^{\circ} \mathrm{C}$ y $1.000^{\circ} \mathrm{C}$, bajo las mismas condiciones experimentales descritas para los morteros.

Posterior a la exposición a las temperaturas en estudio, se determinaron los cambios de color, la pérdida en peso, pérdida de resistencia a la compresión, y el volumen de poros permeables de todas las muestras en estudio, siguiendo las normativas descritas en la sección 2.3.
$400 \mathrm{~kg}$ percubic metre of concrete. This amount of binder has been selected based on the results of previous studies $(24,26)$. Only concretes with a slag/(slag+metakaolin) ratio of 1.0 and 0.4 , and water/(slag+metakaolin+anhydrous activator) of 0.6 were produced. Admixtures were not added to the fresh concrete mixtures, which were moulded in cylindrical moulds with a diameter of $76.2 \mathrm{~mm}$ and height of 152.4 mm for most tests.

\subsection{Tests conducted}

For mortar samples, compressive strength was measured in accordance with the standard test method ASTM C109 after 7, 28 and 60 days of curing. The mechanical properties of the concrete were evaluated after 7 and 28 days of curing. For concrete samples, compressive strength was determined following the standard method ASTM C39, splitting tensile strength according to the standard test method ASTM C496, and flexural strength was assessed on beams with dimensions of $102 \times 102 \times 274 \mathrm{~mm}$ according to the three-point method described in the standard method ASTM C78. The volume of permeable pores of these specimens was obtained following the ASTM C642 method. According to this test method specimens are dried at $100{ }^{\circ} \mathrm{C}$ for $24 \mathrm{~h}$, then submerged in water for $48 \mathrm{~h}$ to determine the saturated mass after immersion; then the specimens are boiled at $100{ }^{\circ} \mathrm{C}$ for $5 \mathrm{~h}$ and the saturated mass after boiling and immersed apparent mass are obtained.

\subsection{Exposure to high temperatures}

The study of performance at high temperatures was conducted using samples of mortars and concretes after 28 days of curing. In the case of mortars, samples were exposed at $200^{\circ} \mathrm{C}$ and $600^{\circ} \mathrm{C}$ for two hours, at a heating rate of $10^{\circ} \mathrm{C} / \mathrm{min}$ until reaching the desired exposure temperature, and then slow natural cooling inside the oven. Concretes were exposed at $200^{\circ} \mathrm{C}, 400^{\circ} \mathrm{C}$, $600^{\circ} \mathrm{C}, 800^{\circ} \mathrm{C}$ and $1000^{\circ} \mathrm{C}$, under the same experimental conditions described for mortars.

After exposure tohigh temperatures, changes in colour, weight, compressive strength, and the volume of permeable pores were assessed, following the methods described in section 2.3. 


\section{RESULTADOS Y DISCUSIÓN}

\subsection{Caracterización de morteros y hormigones basados en mezclas de escoria/metacaolín activadas alcalinamente}

\subsubsection{Resistencia a la compresión de morteros}

La resistencia a la compresión de los morteros en estudio a diferentes edades de curado se muestra en la Figura 1 , donde se observa que a edades tempranas de curado (7 días), la incorporación de escoria siderúrgica en proporciones de hasta un $60 \%$ induce una ligera reducción en la resistencia a la compresión, respecto de lo que se observa en morteros con menores contenidos de metacaolín. Esto puede ser atribuido a la elevada alcalinidad que se utilizó para la activación de estos cementantes, la cual puede dificultar la disolución de calcio presente en la escoria a los primeros tiempos de curado y, por lo tanto, retardar la formación de los productos de reacción que contribuyen al desarrollo mecánico del material derivados de la activación de este precursor.

A edades de curado más avanzadas, se observa que los morteros que contienen $20 \%$ de escoria presentan la resistencia a la compresión más baja de los morteros en estudio, y no se identifica un incremento en la resistencia mecánica con mayores tiempos de curado (60 días). Esto indica que estos morteros han alcanzado la mayor parte de su capacidad portante a los 28 días de curado.

Una tendencia similar es identificada en morteros elaborados con $40 \%$ de escoria pero el incremento en la resistencia entre 7 y 28 días de curado es más notable en morteros con los menores contenidos de escoria. La inclusión de escoria en la matriz geopolimérica en proporciones mayores al $60 \%$ inducen al desarrollo de resistencias mecánicas de hasta $60 \mathrm{MPa}$ a 28 días de curado, y no se identifican diferencias significativas en la resistencia mecánica con un curado adicional de las muestras.

\section{RESULTS AND DISCUSSION}

\subsection{Characterisation of mortars and concretes based on alkali-activated slag/metakaolin blends}

\subsubsection{Compressive strength of mortars}

The compressive strengths of the mortars studied at different ages of curing are shown in Figure 1, where it can be seen that at early age ( 7 days), the incorporation of granulated blast furnace slag in proportions up to 60 $w t . \%$ induces a slight reduction incompressive strength. This could be attributed to the high alkalinity that was used for the activation of the binders, which will hinder the dissolution of calcium present in the slag at early age, and therefore retard the formation of reaction products derived from the activation of the slag, which would otherwise be able to contribute to the mechanical development of the material.

At more advanced ages of curing, it is observed that mortars containing $20 \%$ slag report the lowest compressive strength of the materials studied, and no increment in the mechanical strength is identified for this composition at longer times of curing (60 days). This indicates that those mortars have reached their full loading capacity after 28 days of curing.

A similar trend is identified in mortars prepared with $40 \%$ slag, but the increment in strength from 7 to 28 days is more notable than for mortars with lower contents of slag. The inclusion of more than $60 \%$ slag in the geopolymer matrix gives the development of compressive strengths approaching $60 \mathrm{MPa}$ after 28 days of curing, and there is no significant difference in the compressive strength of these samples with further curing.

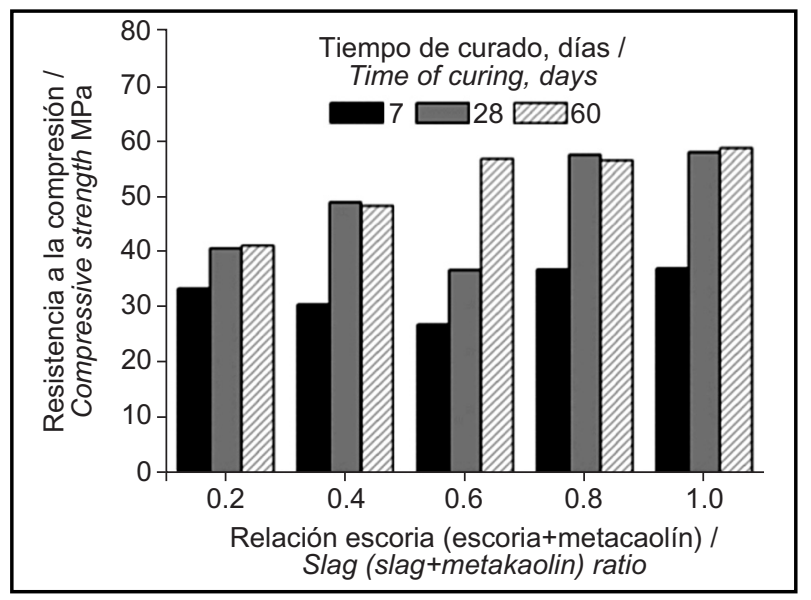

Figura 1. Resistencia a la compresión de morteros de activación alcalina en función de la edad de curado. Figure 1. Compressive strength of alkali-activated mortars as function of the age of curing. 
Estos resultados son coherentes con lo identificado en otros estudios $(11,27,28)$ donde se reportan resistencias a la compresión más elevadas en geopolímeros basados en metacaolín con incorporación de mayores contenidos de escoria. Esto es atribuido al suministro de iones $\mathrm{Ca}^{2+}$ tras la disolución de la escoria, favoreciendo la formación simultánea de geles del tipo silicato cálcico hidratado (C-A-S-H) y del tipo aluminosilicato $(\mathrm{N}-\mathrm{A}-\mathrm{S}-\mathrm{H})(27)$, y la posible interacción de los iones $\mathrm{Ca}^{2+}$ con la red geopolimérica compuesta por enlaces del tipo Si-O-Al, contribuyendo al balance de cargas de los lugares tetraédricos del Al(III), en lugar de los cationes del metal alcalino provenientes de la solución activante (29). Cuando el contenido de escoria es menor de un $40 \%$, el gel cementante que domina la estructura del material es el gel de aluminosilicato, el cual presenta una menor densidad que el gel de C-A-S-H, y consecuentemente promueve el desarrollo de una menor resistencia mecánica $(11,28,30)$. Por el contrario, una mayor proporción de escoria promueve una estructura dominada por un gel del tipo C-A-S-H, el cual contribuye significativamente al mejoramiento de la resistencia mecánica.

\subsubsection{Propiedades mecánicas de hormigones}

En general, los hormigones elaborados presentaron una elevada trabajabilidad durante los primeros 10 minutos posteriores a su mezclado, con una consistencia similar a la esperada en hormigones del tipo autocompactante, facilitando su colocación en los moldes utilizados. Posteriormente, los hormigones presentaron una pérdida drástica de la trabajabilidad, especialmente en aquella mezcla basada únicamente en escoria activada alcalinamente. Esto es coherente con el incremento en los tiempos de fraguado identificado en pastas de escoria activada alcalinamente con la incorporación de metacaolín (21). En la Figura 2
These results are consistent with those identified in other studies $(11,27,28)$, reporting improved mechanical strength in geopolymers based on metakaolin with the addition of higher contents of slag. This is attributed to the supply of $\mathrm{Ca}^{2+}$ made available by the dissolution of the slag, favouring the simultaneous formation of calcium silicate hydrate type gels (C-A-S-H) and aluminosilicate type gels $(N-A-S-H)$ (27), and the potential interaction of the $\mathrm{Ca}^{2+}$ cations with the geopolymer gel. This gel is composed of Si-O-Al bonds, and the $\mathrm{Ca}^{2+}$ can contribute to some extent to the charge balancing of the tetrahedral Al(III) sites, in place of alkali cations from the activating solution (29). When the content of slag is lower than $40 \%$, the binding gel dominating the material structure is an aluminosilicate gel, which presents a lower density than the $C-A-S-H$, and consequently promotes the development of reduced mechanical strength $(11,28,30)$. An increased content of slag promotes a structure dominated by the $C-A-S-H$ type gel, which contributes to the significant improvement of the mechanical strength.

\subsubsection{Mechanical properties of concretes}

In general, the concretes prepared showed a high workability during the first 10 minutes after mixing, with a consistency comparable to self-compacting concrete, making the moulding of the specimens relatively easy. Afterwards, the concretes presented a drastic loss of workability, especially those mixes solely based on alkaliactivated slag. This is consistent with the increased setting time identified in alkali-activated slag pastes with the addition of metakaolin (21). Figure 2 shows the cross-sections of the concretes studied, where the adequate distribution of aggregates and absence of

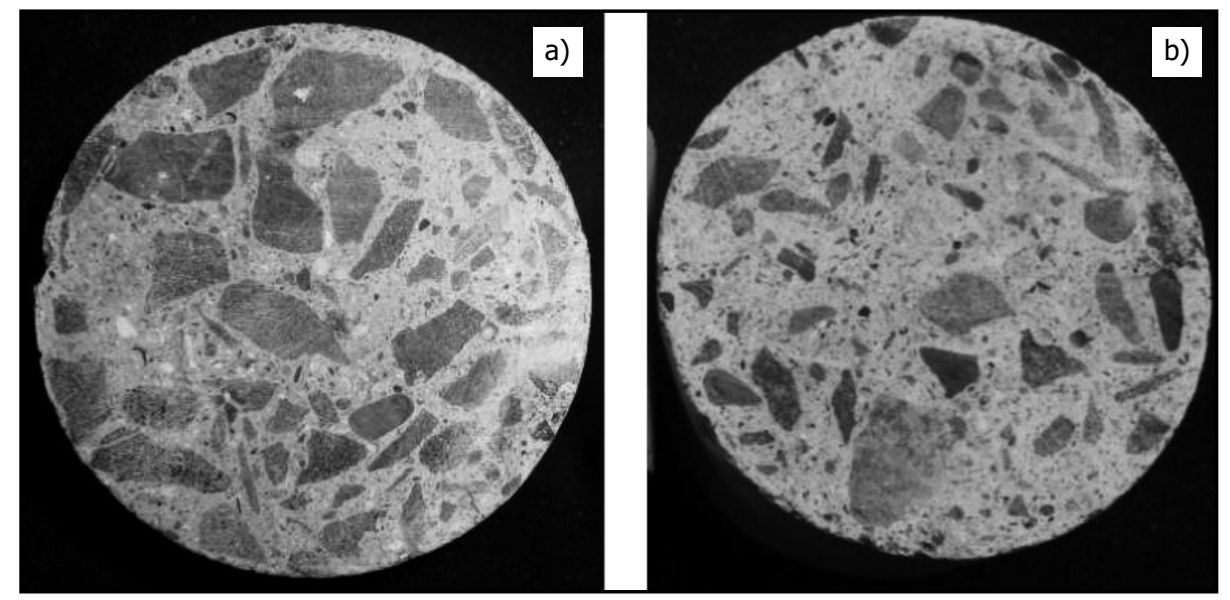

Figura 2. Corte transversal de los hormigones de mezclas de escoria/metacaolín activada alcalinamente con a) $0 \%$ MK y b) $60 \%$ MK, posterior a 28 días de curado.

Figure 2. Cross sections of alkali-activated slag/metakaolin blended concretes with a) $0 \%$ MK and b) $60 \%$ MK, after 28 days of curing. 
Tabla 4 / Table 4

Propiedades mecánicas de hormigones basados en escoria/metacaolín activados alcalinamente. Mechanical properties of concretes based on alkali-activated slag/metakaolin blends.

\begin{tabular}{|c|c|c|c|c|}
\hline $\begin{array}{c}\text { Relación escoria / } \\
\text { (escoria+metacaolín) / } \\
\text { Slag / (slag+metakaolin) } \\
\text { ratio }\end{array}$ & \multicolumn{2}{|c|}{$\begin{array}{c}\text { Resistencia a la compresión / } \\
\text { Compressive strength, MPa }\end{array}$} & $\begin{array}{c}\text { Resistencia a la tracción } \\
\text { indirecta / Splitting tensile } \\
\text { strength, MPa }\end{array}$ & $\begin{array}{c}\text { Resistencia a la flexión / } \\
\text { Flexural strength, MPa }\end{array}$ \\
\cline { 2 - 5 } & $\mathbf{7}$ días / days & $\mathbf{2 8}$ días / days & $\mathbf{2 8}$ días / days & $\mathbf{2 8}$ días / days \\
\hline 1.0 & $30.3 \pm 1.9$ & $37.6 \pm 1.2$ & $4.32 \pm 0.24$ & $2.39 \pm 0.12$ \\
\hline 0.4 & $25.7 \pm 1.8$ & $35.3 \pm 1.9$ & 0.20 & $4.04 \pm 0.09$ \\
\hline
\end{tabular}

se presenta un corte transversal de los hormigones producidos, donde se observa una adecuada distribución de los áridos, a pesar de la elevada fluidez que exhibieron durante los primeros minutos de colocación.

Los resultados de la resistencia a la compresión, tracción indirecta y flexión de los hormigones en estudio se presentan en la Tabla 4. La inclusión de MK en el cementante conduce a la reducción de la resistencia a la compresión a edades tempranas de curado, lo que es coherente con lo identificado en morteros (Figura 1) elaborados con cementantes con una formulación similar. Sin embargo, la resistencia a la compresión de los hormigones con una edad de curado de 28 días incluyendo $60 \%$ de $\mathrm{MK}$ es comparable a aquella reportada por hormigones basados únicamente en escoria siderúrgica. Cabe anotar que estos valores de resistencia a la compresión son menores a lo identificado en estudios anteriores en hormigones basados en cementantes binarios de escoria/metacaolín activados alcalinamente (24), y aquellos basados únicamente en escoria siderúrgica $(24,26)$. Esto podría asociarse a la elevada relación agua/cementante utilizada para la producción de los hormigones en el presente estudio (relación 0,6). La inclusión del $60 \%$ de metacaolín en la mezcla reduce a la mitad la resistencia a la tracción indirecta de los hormigones de escoria activada alcalinamente; sin embargo, no se identifican diferencias significativas en la resistencia a la flexión.

\subsection{Efecto de la exposición a temperaturas elevadas}

\subsubsection{Caracterización de morteros expuestos a temperaturas elevadas}

La determinación de la pérdida en peso de materiales expuestos a temperaturas elevadas permite identificar el rango de temperaturas a las cuales tienen lugar las principales transformaciones estructurales en el material. En los morteros en estudio se identifica la mayor pérdida de peso (Figura 3) a los menores contenidos de escoria (20\% y $40 \%$ ) a las dos temperaturas de exposición $\left(200{ }^{\circ} \mathrm{C}\right.$ y $600{ }^{\circ} \mathrm{C}$ ). Los morteros formulados con $60 \%$ de escoria reportan la pérdida de peso más reducida, cuando son segregation can be seen, despite the high fluidity exhibited during the first minutes of moulding.

Compressive strength, splitting tensile strength and flexural strength results for the concretes studied are reported in Table 4. The inclusion of $M K$ in the binder leads to reduction in the mechanical strength at early ages of curing, which is consistent with the trends identified in mortars (Figure 1) produced with binders with similar formulations. However, the 28-day compressive strength of concretes with $60 \% \mathrm{MK}$ is comparable with that of concretes solely based on alkaliactivated slag. It is noted that the compressive strength values are lower than those identified in previous studies in concretes based on alkali-activated slag/metakaolin blends formulated with lower contents of metakaolin than those assessed in this study (24), and also those solely based on slag $(24,26)$. This could be a consequence of the higher water/binder ratio (0.6) used for the production of the concretes in this study. The inclusion of $60 \% \mathrm{MK}$ in the mixture reduced the splitting tensile strength by almost half; however, no significant differences in the flexural strength are identified.

\subsection{Effects of exposure to high temperatures}

\subsubsection{Characterisation of mortars exposed to high temperatures}

The determination of the weight loss of materials exposed to high temperatures allows identification of the range of temperatures at which the main structural transformations are taking place. In the mortars assessed, a higher weight loss is identified (Figure 3) at lower contents of slag (20\% and $40 \%)$ at the two temperatures of exposure $\left(200^{\circ} \mathrm{C}\right.$ and $\left.600^{\circ} \mathrm{C}\right)$. The mortars formulated with $60 \%$ slag report the lower weight loss when exposed at $200^{\circ} \mathrm{C}$; however, those 
expuestos a $200^{\circ} \mathrm{C}$; sin embargo, esta mezcla reporta una pérdida de peso comparable a las otras mezclas en estudio cuando es expuesta a $600{ }^{\circ} \mathrm{C}$.

Estos resultados son coherentes con las características estructurales de los geles cementantes que se forman en el material con los diferentes contenidos de sustitución de metacaolín por escoria. Se ha identificado (11) que en este tipo de mezclas cementantes la estructura es dominada por un gel del tipo aluminosilicato cuando los contenidos de escoria son menores al $40 \%$, la cual presenta poros de gran tamaño con agua libre que favorece la pérdida en peso a bajas temperaturas (31). Esta pérdida de peso es asociada a la remoción de los grupos hidroxilo que pueden estar condensados en la superficie del gel cementante $(12,32)$, y del agua químicamente enlazada que está presente en los productos de reacción de tipo zeolítico, que se forman en los sistemas de metacaolín activado alcalinamente (33).

En cementantes basados en mezclas de escoria/metacaolín activadas alcalinamente con un contenido de escoria mayor a $60 \%$, se ha identificado (11) que la estructura es dominada por el gel del tipo C-A-S-H con un alto grado de sustitución de $\mathrm{Al}$ y posible inclusión de sodio (C-(N)-A-S-H). Considerando las pérdidas en peso de los morteros en estudio (Figura 3), es posible inferir que este gel presenta un menor contenido de agua libremente atrapada, y por lo tanto se reportan menores pérdidas en peso a temperaturas bajas $\left(200^{\circ} \mathrm{C}\right)$ de exposición.

La resistencia a la compresión residual de los morteros en estudio, determinada a partir de la relación de la resistencia mecánica de estos materiales antes y después de la exposición a temperaturas altas se presenta en la Figura 4. Se observa que posterior a la exposición a $200{ }^{\circ} \mathrm{C}$ durante dos horas, los morteros con el menor contenido de escoria ( $<40 \%)$ presentan las mayores reducciones en la resistencia a la compresión, siendo ello coherente con la pérdida de peso reportada por estos especímenes (Figura 3). Los morteros con mayores contenidos de escoria (60\%-100\%) presentan (Figura 4) resistencias a la compresión residual de hasta un $96 \%$ con el incremento de escoria en el cementante. Esto es, a su vez, coherente con la reducida pérdida de peso identificada en estos materiales a las condiciones en estudio, asociado ello a una menor pérdida de agua libre.

La exposición a temperaturas más elevadas $\left(600^{\circ} \mathrm{C}\right)$ conduce a reducciones en la resistencia a la compresión de solo un $18 \%$ y $10 \%$ en morteros formulados con $20 \%$ y $40 \%$ de escoria, respectivamente, cuando son comparados con la resistencia residual reportada por estos materiales después de la exposición a $200^{\circ} \mathrm{C}$. Las mayores pérdidas de resistencia a esta temperatura son reportadas por morteros con contenidos superiores al $60 \%$ de mixes show a weight loss comparable with the other mixes assessed when exposed to $600^{\circ} \mathrm{C}$.

Those results are consistent with the structural characteristics of the binding gels forming in the material at the different levels of metakaolin substitution for slag. It has been identified (11) that in these types of blended binders the structure is dominated by an aluminosilicate type gel at slag contents lower than 40\%, which presents larger pores containing free water, thus favouring weight loss at lower temperatures (31). The consequent weight loss is associated with the removal of the hydroxyl groups from the surface of the binding gel $(12,32)$, and the zeolitic-like water that is present in the reaction products formed in geopolymers based on alkali-activated metakaolin (33).

In alkali-activated slag/metakaolin blends with slag contents higher than $60 \%$, it has been identified (11)that the structure is governed by a C-A-S-H type gel with a high degree of $A$ l substitution and possible inclusion of sodium (C-(N)-A-S-H). Considering the weight loss of the mortars assessed (Figure 3), is possible to infer that these gels present a lower content of trapped molecular water, and therefore show lower weight loss at lower temperatures $\left(200^{\circ} \mathrm{C}\right)$ of exposure.

The residual compressive strengths of the mortars assessed, representing the ratio between the compressive strength after exposure to high temperatures and the compressive strength before exposure, areshown in Figure 4. It can be observed that after exposure to $200^{\circ} \mathrm{C}$ for two hours, the mortars with lower contents of slag $(<40 \%)$ show the greatest reduction in compressive strength, consistent with the weight loss reported for those specimens (Figure 3). The mortars with higher slag contents (60\% to $100 \%$ ) present (Figure 4) residual compressive strengths of up to $60 \%$. This is in good agreement with the reduced weight loss identified in those materials at the exposure conditions assessed, which is associated with the lower molecular water content.

The exposure to higher temperatures $\left(600^{\circ} \mathrm{C}\right)$ leads to reductions of $18 \%$ and $10 \%$ in the compressive strength of mortars formulated with $20 \%$ and $40 \%$ slag respectively, when compared with the residual strengths of materials exposed to $200^{\circ} \mathrm{C}$. The largest strength loss at $600^{\circ} \mathrm{C}$ is observed in mortars with slag contents higher than $60 \%$. These results are consistent with the dehydration of the $\mathrm{C}-\mathrm{S}-\mathrm{H}$ type gels at those 


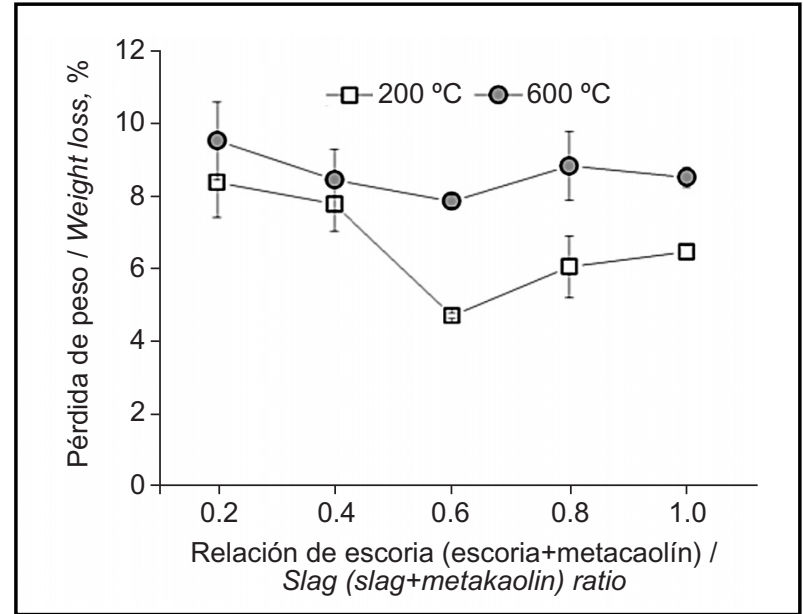

Figura 3. Pérdida de peso de morteros de activación alcalina en función de la temperatura de exposición.

Figure 3. Weight loss of alkali-activated mortars as function of the temperature of exposure.

escoria. Estos resultados son consistentes con la deshidratación que los geles de C-S-H sufren a esta temperatura de exposición, lo que consecuentemente reduce la capacidad portante del material. Cabe anotar, que todos los morteros, independientemente de los contenidos de escoria en el cementante, presentan posterior a la exposición a $600^{\circ} \mathrm{C}$ valores de resistencia residual entre $23 \mathrm{MPa}$ y $25 \mathrm{MPa}$ (50\%-55\% de la resistencia original).

El volumen de poros permeables de los morteros en estudio, posterior a la exposición a una temperatura de $600{ }^{\circ} \mathrm{C}$, determinado de acuerdo al procedimiento estándar ASTM C 642 (excepto el pre-acondicionamiento de las muestras especificado por el estándar), se presenta en la Tabla 5 . Se identifica que el incremento en el contenido de escoria conduce al desarrollo de una menor porosidad de los morteros. Esto es coherente con los resultados obtenidos en cementantes de activación alcalina basados en mezclas de ceniza volante/escoria (30), donde la inclusión de contenidos de escoria superiores promueve la reducción del volumen de poros e incrementa la tortuosidad de la red de poros, asociado ello a la capacidad de los geles cementantes de llenar espacio. Se considera que geles del tipo C-S-H tienen una mayor capacidad de llenar espacios que los geles del tipo aluminosilicato (30), y por lo tanto, cementantes con una estructura dominada por geles del C-S-H presentan una menor permeabilidad que aquellos con una estructura dominada por geles del tipo aluminosilicato. La exposición a $600^{\circ} \mathrm{C}$ conlleva a un incremento significativo de la porosidad de todas las muestras en estudio, siendo más significativo en las muestras con los menores contenidos de escoria $(0 \%$, $20 \%$ y $40 \%$ escoria).

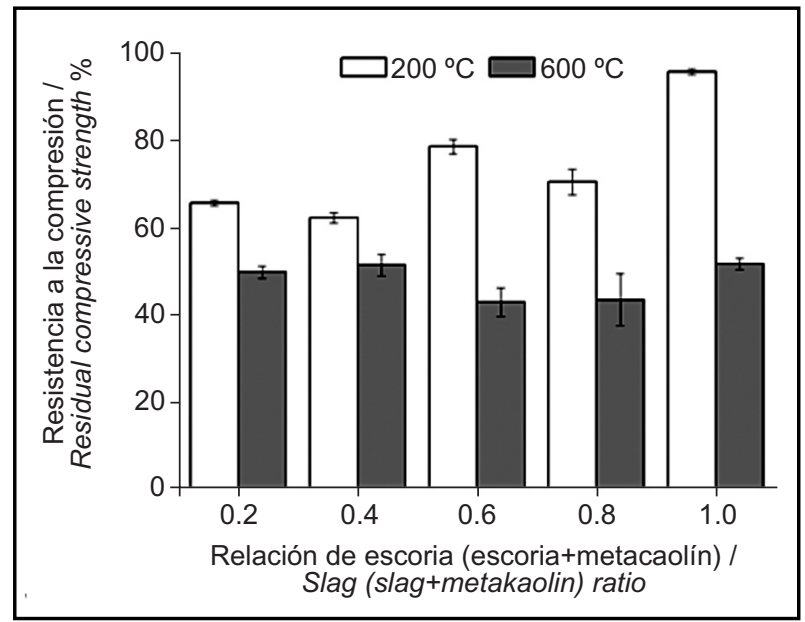

Figura 4. Resistencia a la compresión residual de morteros de activación alcalina posterior a la exposición a temperaturas elevadas.

Figure 4. Residual compressive strength of alkali-activated mortars after the exposure to elevated temperatures.

temperatures, and the consequent loss of loading capacity of the material. It is noted that all mortars, independent of the content of slag in the binder, exhibit after exposure to $600{ }^{\circ} \mathrm{C}$ residual strength values between $23 \mathrm{MPa}$ and $25 \mathrm{MPa}$ (50\%-55\% of the original strength).

The volume of permeable pores of the mortars assessed after exposure to $600^{\circ} \mathrm{C}$, determined following the standard procedure ASTM C 642 (except for the provisions in that standard regarding sample conditioning) is shown in Table 5. It can be seen that an increased content of slag leads to reduced porosity in mortars. This is consistent with the results obtained in alkali-activated binders based on fly ash/slag blends (30), where the inclusion of higher contents of slag promotes a reduction in the volume of pores and increases the tortuosity of the pore networks, associated with the space-filling capacity of the gel. It is considered that the $\mathrm{C}-\mathrm{S}-\mathrm{H}$ is more space-filling that aluminosilicate type gels (30), and therefore, binders with a structure dominated by $\mathrm{C}-\mathrm{S}-\mathrm{H}$ have a lower permeability that those with a structure dominated by aluminosilicate type gel. Exposure to $600^{\circ} \mathrm{C}$ leads to a significant increment in the porosity of all the samples assessed, and more soin samples with lower contents of slag (0\%, 20\% and $40 \%)$. 
Tabla 5 / Table 5

Volumen de poros permeables de morteros de activación alcalina expuestos a temperaturas elevadas. Volume of permeables pores of alkali-activated mortars exposed to high temperatures.

\begin{tabular}{|c|c|c|}
\hline \multirow{2}{*}{$\begin{array}{c}\text { Relación escoria/ (escoria+metacaolín) / } \\
\text { Slag/(slag+metakaolin) ratio }\end{array}$} & Antes de exposición / Before exposure & $\begin{array}{c}\text { Volumen de poros permeables / Volume of permeable pores, \% } \\
\text { Defter exposure to } 600{ }^{\circ} \mathrm{C}, \%\end{array}$ \\
\cline { 2 - 3 } & 5.63 & 10.58 \\
\hline 0.8 & 5.90 & 15.44 \\
\hline 0.6 & 8.11 & 16.82 \\
\hline 0.4 & 8.70 & 17.00 \\
\hline 0.2 & 9.55 & 17.46 \\
\hline
\end{tabular}

Adicionalmente a las transformaciones que tienen lugar en la matriz cementante, que generalmente conducen a una elevada contracción debido a la deshidratación de los principales productos de reacción, es posible que la transformación mineralógica de cuarzo- $\alpha$ a cuarzo- $\beta$ de los áridos finos, que ocurren entre $570^{\circ} \mathrm{C}$ y $595^{\circ} \mathrm{C}$ (34, 35), conduzca a cambios volumétricos de los mismos, y consecuentemente a la inducción de fisuras en el material. Este microfisuramiento es atribuido a las diferencias en los coeficientes de expansión térmica entre la matriz y los áridos (36). Esto es coherente con la expansión térmica identificada en geopolímeros basados en cenizas volantes con bajos contenidos de cuarzo en un rango de temperaturas entre $300^{\circ} \mathrm{C}$ y $580{ }^{\circ} \mathrm{C}$ (37). Asimismo, se ha reportado la formación de micro-fisuras en la superficie de partículas de cuarzo a $600{ }^{\circ} \mathrm{C}$ (35), lo que podría favorecer la absorción de agua de los morteros posterior a la exposición a esta temperatura, contribuyendo al incremento del valor de la porosidad total del material.

\subsubsection{Caracterización de hormigones expuestos a temperaturas elevadas}

La pérdida de peso de los hormigones en estudio se reporta en la Figura 5 . A temperaturas de exposición menores a $400{ }^{\circ} \mathrm{C}$ los hormigones que contienen $60 \%$ de metacaolín presentan pérdidas de peso de hasta un $40 \%$ superior a las reportadas por hormigones basados únicamente en escoria. No se observan diferencias significativas en la pérdida de peso de los hormigones que contienen $60 \%$ de metacaolín a temperaturas de exposición entre $400^{\circ} \mathrm{C}$ y $800^{\circ} \mathrm{C}$, lo cual sugiere que la deshidratación completa de los geles cementantes ha ocurrido a menores temperaturas de exposición. La pérdida de peso adicional identificada en los hormigones que contienen metakaolin con la exposición a $1.000^{\circ} \mathrm{C}$ es probablemente asociada con la deshidratación del caolín en el sistema que no ha reaccionado aún, considerando que White et al. (38) ha identificado la presencia de agua residual químicamente enlazada en muestras de metacaolín calcinado a $750^{\circ} \mathrm{C}$.
In addition to the transformations taking place in the binding matrix,leading to shrinkage due to the dehydration of the main reaction products, it is also possible that the mineralogical transformation from $\alpha$-quartz to $\beta$-quartz in the fine aggregates, taking place between $570-595^{\circ} \mathrm{C}(34,35)$, leads to volumetric changes and consequently induces cracking in the material. This microcracking is attributed to the differences (in magnitude and sign) between the thermal expansion coefficients ofthe matrix and the aggregates (36). This is consistent with the thermal expansion behaviour identified in geopolymers based on fly ash with low quartz contents between $300-580^{\circ} \mathrm{C}$ (37). Likewise, the formation of micro-cracks has been reported in the surface of polycrystalline quartz particles at $600^{\circ} \mathrm{C}(35)$, which could also favour the absorption of water in mortars after exposure to high temperature, contributing to increased total porosity measurements.

\subsubsection{Characterisation of concretes exposed to high temperatures}

The weight loss of the concretes assessed is reported in Figure 5. At temperatures of exposure lower than $400{ }^{\circ} \mathrm{C}$, the concretes formulated with $60 \%$ metakaolin show weight losses up to $40 \%$ higher than the concretes solely based on slag. There are not significant differences in the weight loss of concrete containing $60 \%$ of metakaolin after exposure to temperatures between $400^{\circ} \mathrm{C}$ and $800^{\circ} \mathrm{C}$, which suggests that the complete dehydration of the binding gels has taken place at lower temperatures of exposure. The additional weight loss identified in the metakaolin-containing concrete between $800-1000{ }^{\circ} \mathrm{C}$ is likely to be associated with the final stages of dehydration of the unreacted kaolin, considering that White et al.(38) identified the presence of residual chemically bonded water in kaolin calcined at $750^{\circ} \mathrm{C}$. 


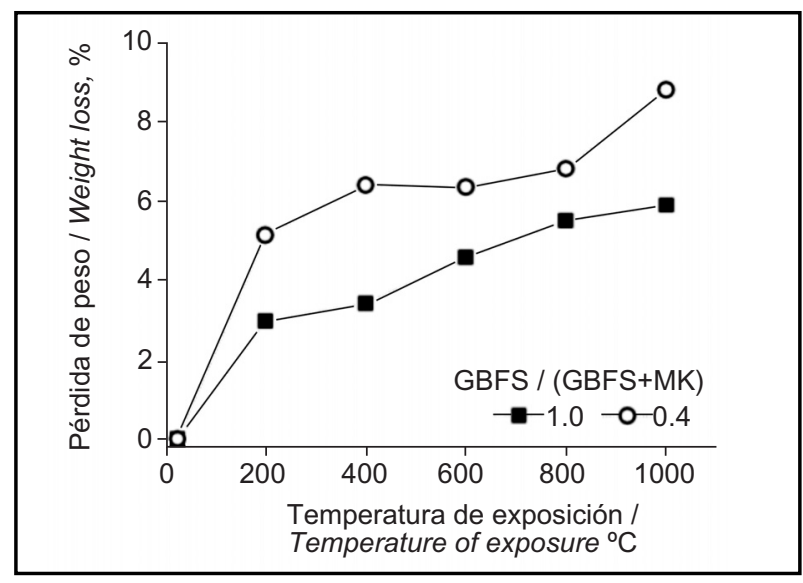

Figura 5. Pérdida en peso de hormigones de activación alcalina en función de la temperatura de exposición.

Figure 5. Weight loss of alkali-activated concretes as a function of the temperature of exposure.

Por su parte hormigones basados únicamente en escoria activada alcalinamente exhiben una pérdida progresiva de peso con el incremento de la temperatura de exposición. A temperaturas inferiores a $400^{\circ} \mathrm{C}$ la pérdida de peso es atribuida a la deshidratación de agua libre y químicamente enlazada en el gel tipo C-S-H (39-42). La pérdida de peso a temperaturas entre $400^{\circ} \mathrm{C}$ y $800^{\circ} \mathrm{C}$ en estos hormigones es atribuida a la descomposición de los carbonatos que se han identificado en la escoria sin reaccionar utilizada en este estudio, y, por lo tanto, están también presentes en los productos cementantes elaborados con esta escoria (41).

La pérdida de peso de los hormigones evaluados es menor que lo identificado en los correspondientes morteros. Esto puede ser en parte consecuencia del menor contenido de cementante en los hormigones. Sin embargo, la formación de una zona de transición o las interacciones químicas entre áridos y la matriz cementante pueden estar contribuyendo a las diferencias en el desempeño identificado entre morteros y hormigones, e investigación en esta área debe ser llevada a cabo para generar un mejor entendimiento de los fenómenos que ocurren en hormigones de activación alcalina cuando son expuestos a temperaturas elevadas.

A pesar de que los hormigones formulados con $60 \%$ de metacaolín presentaron mayores pérdidas en peso que aquellos producidos únicamente con escoria siderúrgica activada alcalinamente (Figura 5), la resistencia a la compresión residual a las diferentes temperaturas de exposición de ambos concretos son comparables (Figura 6). Estos resultados son concordantes con la tendencia identificada en morteros (Figura 4); sin embargo, la resistencia residual en morteros fue un $40 \%$ superior a los valores reportados por los hormigones a las diferentes

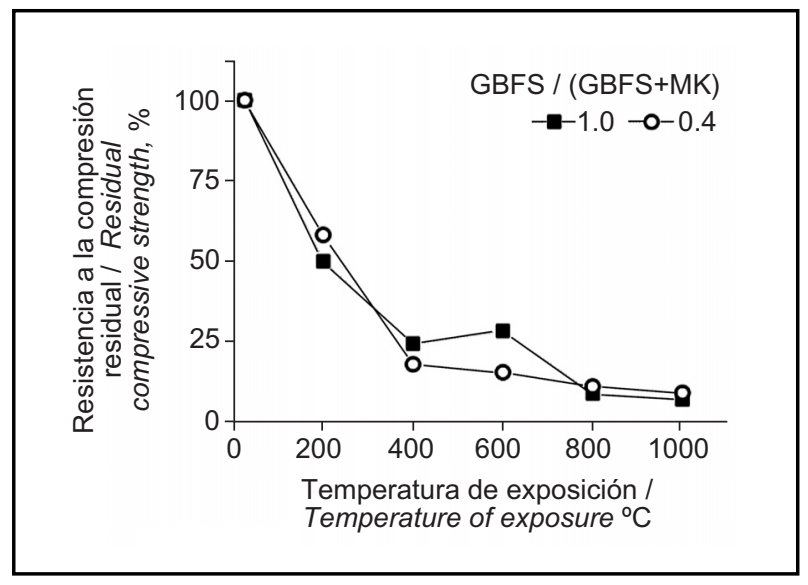

Figura 6. Resistencia a la compresión residual de hormigones de activación alcalina posterior a la exposición a temperaturas elevadas.

Figure 6. Residual compressive strength of alkali-activated concretes after the exposure to elevated temperatures.

On the other hand, concretes solely based on alkaliactivated slag exhibit a progressive weight loss with increasing exposure temperature. At temperatures lower than $400^{\circ} \mathrm{C}$ the weight loss is attributed to the dehydration of free and chemically bonded water present in the $\mathrm{C}-\mathrm{S}-\mathrm{H}$ (39-42). The weight loss at temperatures between $400^{\circ} \mathrm{C}$ and $800^{\circ} \mathrm{C}$ is likely to be a consequence of the decomposition of calcium carbonates, which have been identified in the unreacted slag used in this study, and therefore are also present in the alkali-activated binders produced from this slag (41).

The weight loss of the concretes assessed is lower than is identified in the corresponding mortars. This may be in part a consequence of the slightly lower binder content in the concretes. However, the formation of a transition zone or chemical interactions between coarse aggregates and the binding matrix could also be contributing to the differences in performance identified between mortars and concretes, and further research in this area should be conducted in order to generate a better understanding of the phenomena occurring in alkali-activated concretes exposed to high temperatures.

Although the concretes formulated with $60 \%$ metakaolin show higher weight loss compared with those solely based on alkali-activated slag (Figure 5), the residual compressive strengths of the two concretes at the different temperatures of exposure are comparable (Figure 6). This is consistent with the trend identified in mortars (Figure 4); however, the residual strengths of the mortars are $40 \%$ higher than the values obtained for concretes at the corresponding temperatures of exposure. This indicates that the inclusion of coarse 
temperaturas de exposición. Esto indica que la inclusión de áridos gruesos y las potenciales diferencias en los coeficientes de expansión térmica de los mismos, respecto de las matrices cementantes están contribuyendo al elevado microfisuramiento del material (Figura 7), y la consecuente pérdida de resistencia mecánica.

Los valores de resistencia residual de los hormigones en estudio son menores a lo obtenido por Guerrieri et al. (16) en hormigones de cemento Portland y de escoria siderúrgica activada alcalinamente expuestos a temperaturas de hasta $1.200^{\circ} \mathrm{C}$. Las diferencias más significativas en resistencia residual de los hormigones en estudio y lo reportado en (16) se identifican a temperaturas de exposición de hasta $600^{\circ} \mathrm{C}$; sin embargo, los valores de resistencia residual de los especímenes expuestos a $800^{\circ} \mathrm{C}$ y $1.000^{\circ} \mathrm{C}$ son comparables a lo identificado por Guerrieri et al. (16). Las diferencias en desempeño son atribuidas al menor tiempo de exposición ( $1 \mathrm{~h}$, comparado con $2 \mathrm{~h}$ en este estudio) de los especímenes a las diferentes temperaturas de exposición en el estudio conducido por Guerrieri et al. (16), y a la reducida relación agua/cementante (relación de 0.5) usada para la elaboración de aquellos hormigones. Mayores tiempos de exposición a temperaturas elevadas de hormigones formulados con relaciones agua/cementante más altas promueven una mayor deshidratación de los productos de reacción a las diferentes temperaturas de exposición, y favorecen la formación de grietas de mayor tamaño, lo que consecuentemente tiene un mayor impacto en el desempeño mecánico del material.

Es importante mencionar que los valores de resistencia residual reportados por los hormigones en estudio, son solo un $10 \%$ inferiores a lo identificado (43) en hormigones de cementos Portland de alto desempeño reforzados con fibras de acero y polipropileno expuestos a temperaturas de $800^{\circ} \mathrm{C}$, donde se espera un mejor control dimensional de los especímenes por efecto de la inclusión de fibras. Esto resalta la elevada estabilidad a temperaturas elevadas que tienen los hormigones basados en cementos alcalinos.

En la Figura 7 se presentan las fotografías de los hormigones en estudio a las diferentes temperaturas de exposición. No se identifican variaciones significativas en la apariencia de los hormigones a temperaturas de exposición de hasta $400^{\circ} \mathrm{C}$; sin embargo, posterior a la exposición a $1.000{ }^{\circ} \mathrm{C}$, los hormigones elaborados con un contenido de escoria del $40 \%$ presentan, además de una coloración rojiza, la formación de grietas de gran tamaño. Este fisuramiento puede ser atribuido a la contracción volumétrica identificada en materiales basados en metacaolín activado alcalinamente a esta temperatura de exposición (11-13, 44). Cabe anotar, que el gel de aluminosilicato se densifica a una temperatura de $800^{\circ} \mathrm{C}$, aggregates, and particularly the differences between the thermal expansion of these particles and the binding matrix, is contributing to significant microcracking of the material (Figure 7) and the consequent loss of mechanical strength.

The residual strength values of the concretes assessed are lower than those obtained by Guerrieri et al. (16) for Portland cement concretes and alkali activated slag concretes exposed to temperatures of up to $1200^{\circ} \mathrm{C}$. The most significant differences in the residual strengths determined here and those reported elsewhere (16) are identified when the samples are exposed to temperatures up to $600{ }^{\circ} \mathrm{C}$; however, the values of residual strength of the specimens exposed at $800^{\circ} \mathrm{C}$ and $1000^{\circ} \mathrm{C}$ are comparable to those identified by Guerrieri et al. (16). The differences in the material performance are attributed to the reduced time of exposure (1 h, compared to $2 \mathrm{~h}$ here) of the specimens of Guerrieri et al. (16), and the reduced water/binder ratio (0.5, compared to 0.6 here) used for the production of those concretes. Longer times of exposure to high temperatures, and formulation of concretes with higher water/binder ratios, promotes a greater extent of dehydration of reaction products at each temperature of exposure, favouring the formation of large cracks and impacting the strength of the material.

However, it is important to note that the residual strengths of the concretes assessed here are just $10 \%$ lower than those reported for high performance Portland cement concrete reinforced with steel and polypropylene fibres after exposure to $800^{\circ} \mathrm{C}$ (43), where improved dimensional and mechanical stability of the specimens is expected to result from the inclusion of fibres. This highlights the relatively good stability at high temperatures of concretes based on alkali-activated binders, compared to concrete materials in general.

Figure 7 shows photographs of the concretes after hightemperature exposure. There are no significant changes in the appearance of the concretes exposed at temperatures of up to $400^{\circ} \mathrm{C}$. However, after exposure at $1000^{\circ} \mathrm{C}$, alkali-activated concretes produced with $40 \%$ slag and $60 \%$ metakaolin show a reddish coloration and the formation of large cracks. This cracking can be associated with the volumetric contraction identified in materials based on alkaliactivated metakaolin at this temperature of exposure (11-13, 44). Alkali alumino silicate gels derived from metakaolin usually densify at a temperature of $800^{\circ} \mathrm{C}$, as a consequence of the re-ordering of the material, 


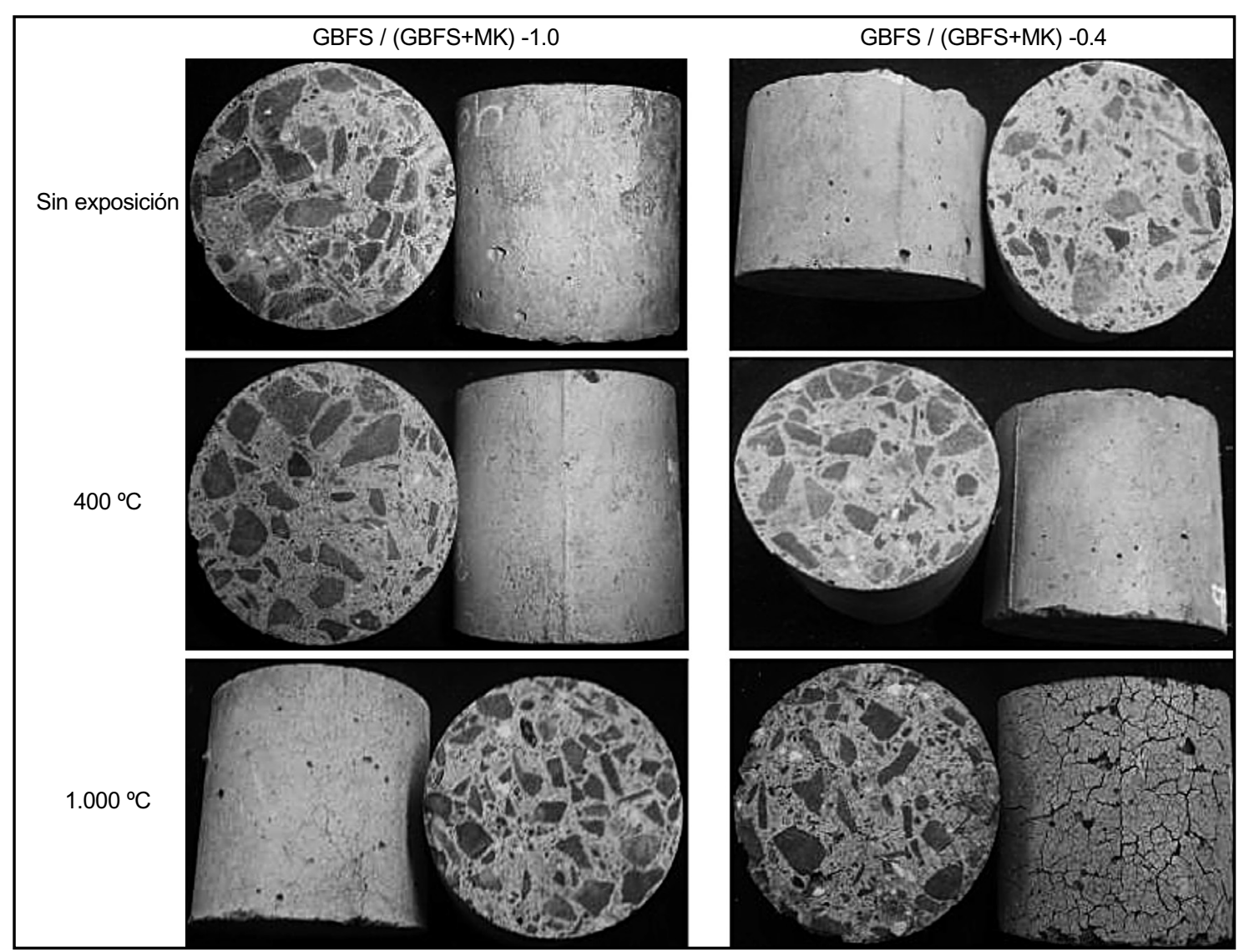

Figura 7. Fotografías de hormigones de activación alcalina expuestos a temperaturas elevadas, en función del contenido de escoria en el cementante.

Figure 7. Photographs of alkali-activated concretes exposed to high temperatures, as a function of the slag content in the binder.

como consecuencia del reordenamiento del material, comparable a un proceso de sinterización viscosa derivada del metacaolín a más de $1.000^{\circ} \mathrm{C}(45)$, lo que conlleva a una elevada contracción del material y su consecuente fisuramiento debido al efecto de los áridos.

Los cambios de color de las muestras en estudio están relacionados con los cambios en los estados de oxidación del hierro presente, durante y posteriores a la exposición a temperaturas elevadas de los óxidos de hierro presentes en la escoria y el metacaolín. Los óxidos de hierro están presentes en la escoria, metacaolín y en los áridos gruesos. En un estudio de areniscas de diferentes procedencias se ha identificado que los cambios más significativos de color son consecuencia de la oxidación de los minerales ricos en hierro a una estructura del tipo hematita, lo que tiene lugar a temperaturas cercanas a los $900{ }^{\circ} \mathrm{C}(35)$

Por su parte, los hormigones basados únicamente en escoria presentan la formación de grietas de menor tamaño cuando son expuestos a temperaturas superiores a $400{ }^{\circ} \mathrm{C}$, respecto de lo identificado en hormigones formulados con comparable to a viscous sintering process evolution of Na-geopolymer derived from metakaolin up to $1000^{\circ} \mathrm{C}$ (45), which leads to the high shrinkage of the material and its consequent cracking due to the restraining effects of the aggregate.

The colour changes of the samples are related to changes in the oxidation state of the iron present, during and after exposure to high temperatures in an air environment. Iron oxides are present in the slag, metakaolin and coarse aggregate. In a study of sandstones from different sources, it was identified that the most significant changes in colour are a consequence of the oxidation of the iron-rich minerals to a hematite type structure, which takes place at temperatures around $900^{\circ} \mathrm{C}(35)$.

On the other hand, concretes based solely on slag show the formation of much smaller cracks following exposure to temperatures higher than $400^{\circ} \mathrm{C}$, when compared with those formulated with $60 \%$ metakaolin. A darkening 
$40 \%$ de MK. De igual manera, se identifica un ligero oscurecimiento (de gris claro a gris oscuro ligeramente rojizo) a temperaturas de exposición de $1.000^{\circ} \mathrm{C}$, siendo esto comparable a lo reportado en morteros de escoria activada alcalinamente expuestos a similares temperaturas (19).

\section{CONCLUSIONES}

La incorporación de metacaolín en materiales basados en escoria activada alcalinamente incrementa los tiempos de fraguado; sin embargo, induce a la reducción de la resistencia mecánica a edades tempranas de curado (7 días); de otra parte, la resistencia mecánica de morteros y hormigones con y sin metacaolín son comparables a edades avanzadas de curado, independientemente del contenido de metacaolín en el cementante.

Los especímenes de hormigones evaluados aquí presentan resistencias residuales de hasta un $14 \%$ de su resistencia original posterior a la exposición a $600{ }^{\circ} \mathrm{C}$, mientras los morteros con una formulación similar reportan una resistencia residual de hasta un $40 \%$ bajo condiciones similares. Esto hace evidente el efecto significativo de las diferencias en las propiedades térmicas entre los agregados y la matriz, conduciendo a la degradación del material compuesto bajo exposición a altas temperaturas. La falla de los hormigones es entonces consecuencia de un efecto combinado de la contracción de la matriz asociada con la deshidratación de los productos de reacción, y las diferencias en expansión térmica entre el cementante y los agregados, induciendo el macrofisuramiento del material a temperaturas de exposición superiores a los $600^{\circ} \mathrm{C}$ independientemente del contenido de metacaolín. No obstante, la resistencia residual posterior a la exposición de los estos hormigones de activación alcalina es comparable a hormigones de alto desempeño basados en cemento Portland reforzados con fibras, cuando son expuestos a condiciones similares, lo que indica que los hormigones de activación alcalina son potencialmente valiosos en aplicaciones donde la resistencia al fuego es importante.

\section{AGRADECIMIENTOS}

Este estudio fue financiado por la Universidad del Valle (Colombia), el Centro de Excelencia de Nuevos Materiales (CENM) y el Patrimonio Autónomo Fondo Nacional de Financiamiento para la Ciencia, la Tecnología y la Innovación "Francisco José de Caldas" Contrato RC - No. 275-2011. La participación de JLP fue financiada por el Australian Research Council, incluyendo financiamiento parcial por el Particulate Fluids Processing Centre. of the specimens (from light grey to a slightly reddishdark grey) is observed in these specimens when exposed to $1000^{\circ} \mathrm{C}$, which is comparable to the changes reported in mortars based on alkali-activated slag exposed to similar temperatures (19).

\section{CONCLUSIONS}

The incorporation of metakaolin in mortars and concretes based on alkali-activated slag helps to control setting time, at the cost of some reduction in mechanical strength at early ages of curing (7 days). On the other hand, the mechanical strengths of both mortars and concretes with and without metakaolin are comparable at advanced ages of curing, independent of the content of metakaolin in the binder.

The concrete specimens studied here present residual strengths of up to $14 \%$ of their original strength after exposure to $600^{\circ} \mathrm{C}$, while mortars produced with similar formulations report residual strengths of up to $40 \%$ under the same conditions. This makes evident the remarkable effect of the differences in thermal properties between aggregates and the matrix, leading to the degradation of the composite material under high temperature exposure. The failure of the concretes is then a consequence of the combined effect of the shrinkage of the matrix associated with the dehydration of the reaction products, and the differences in thermal expansion between the binder and the aggregates, inducing the macrocracking of the material at temperatures of exposure higher to $600^{\circ} \mathrm{C}$, independent of the metakaolin content. Nonetheless, the post-exposure residual strength of these alkali-activated concretes is comparable to that of high-performance fibre-reinforced Portland cement concretes exposed under similar conditions, indicating that alkali-activated concretes are potentially valuable in applications where fire resistance is important.

\section{ACKNOWLEDGEMENTS}

This study was sponsored by the Universidad del Valle (Colombia), the Centro de Excelencia de Nuevos Materiales (CENM) and the Patrimonio Autónomo Fondo Nacional de Financiamiento para la Ciencia, la Tecnología y la Innovación "Francisco José de Caldas" Contrato RC - No. 275-2011. The participation of JLP was sponsored by the Australian Research Council, including partial support through the Particulate Fluids Processing Centre. 


\section{BIBLIOGRAFÍA / BIBLIOGRAPHY}

(1) Juenger, M. C. G.; Winnefeld, F.; Provis, J.; Ideker, J. L.: "Advances in alternative cementitious binders", Cem. Concr. Res., 41 (2011), pp. 1232-1243. http: //dx. doi. org/10. 1016/j. cemconres. 2010. 11. 012.

(2) Shi, C.; Fernández-Jiménez, A.; Palomo, A.: "New cements for the 21st century: The pursuit of an alternative to Portland cement", Cement and Concrete Research, 41 (2011), pp. 750-763. http: //dx. doi. org/10. 1016/j. cemconres. 2011. 03. 016

(3) Duxson, P.; Provis, J. L.; Lukey, G. C.; van Deventer, J. S. J.: "The role of inorganic polymer technology in the development of 'Green concrete"', Cem. Concr. Res., 37 (2007), pp. 1590-1597. http: //dx. doi. org/10. 1016/j. cemconres. 2007. 08. 018

(4) Duxson, P.; Provis, J. L.: "Designing precursors for geopolymer cements", Journal of the American Ceramic Society, 91 (2008), pp. 3864-3869. http: //dx. doi. org/10. 1111/j. 1551-2916. 2008. 02787. x

(5) Alonso, S.; Palomo, A.: "Alkaline activation of metakaolin and calcium hydroxide mixtures: 'Influence of temperature, activator concentration and solids ration", Materials Letters, 47 (2001), pp. 55-62. http: //dx. doi. org/10. 1016/S0167-577X(00)00212-3

(6) Duxson, P.; Fernández-Jiménez, A.; Provis, J. L.; Lukey, G. C.; Palomo, A.; van Deventer, J. S. J.: "Geopolymer technology: The current state of the art", Journal of Materials Science, 42 (2007), pp. 2917-2933. http: //dx. doi. org/10. 1007/s10853-006-0637-z

(7) Granizo, M. L.; Blanco-Varela, M. T.; Palomo, A.: "Influence of the starting kaolin on alkali-activated materials based on metakaolin. Study of the reaction parameters by isothermal conduction calorimetry", Journal of Materials Science, 35 (2000), pp. 6309-6315. http: //dx. doi. org/10. 1023/A: 1026790924882

(8) van Deventer, J. S. J.; Provis, J. L.; Duxson, P.: "Technical and commercial progress in the adoption of geopolymer cement", Minerals Engineering, 29 (2012), pp. 89-104. http: //dx. doi. org/10. 1016/j. mineng. 2011. 09. 009

(9) Barbosa, V. F. F.; MacKenzie, K. J. D.: "Synthesis and thermal behaviour of potassium sialategeopolymers", Materials Letters, 57 (2003) 1477-1482. http: //dx. doi. org/10. 1016/S0167-577X(02)01009-1

(10) Barbosa, V. F. F.; MacKenzie, K. J. D.: "Thermal behaviour of inorganic geopolymers and composites derived from sodium polysialate", Materials Research Bulletin, 38 (2003), pp. 319-331. http: //dx. doi. org/10. 1016/S0025-5408(02)01022-X

(11) Bernal, S. A.; Rodríguez, E. D.; Mejía de Gutiérrez, R.; Gordillo, M.; Provis, J. L.: "Mechanical and thermal characterisation of geopolymers based on silicate-activated metakaolin/slag blends", Journal of Materials Science, 46 (2011), pp. 5477-5486. http: //dx. doi. org/10. 1007/s10853-011-5490-z

(12) Duxson, P.; Lukey, G. C.; van Deventer, J. S. J.: "Thermal evolution of metakaolin geopolymers: Part 1 - Physical evolution", Journal of Non-Crystalline Solids, 352 (2006), pp. 5541-5555. http: //dx. doi. org/10. 1016/j. jnoncrysol. 2006. 09. 019

(13) Bernal, S. A.; Bejarano, J.; Garzón, C.; Mejía de Gutiérrez, R.; Delvasto, S.: Rodríguez, E. D.: "Performance of refractory aluminosilicate particle/fiber-reinforced geopolymer composites, Composites Part B", Engineering, 43 (2012), pp. 1919-1928. http: //dx. doi. org/10. 1016/j. compositesb. 2012. 02.027

(14) Kong, D. L. Y.; Sanjayan, J. G.; Sagoe-Crentsil, K.: "Factors affecting the performance of metakaolin geopolymers exposed to elevated temperatures", Journal of Materials Science, 43 (2008), pp. 824-831. http: //dx. doi. org/10. 1007/s10853-007-2205-6

(15) Cheng, T. W.; Chiu, J. P.: "Fire-resistant geopolymer produced by granulated blast furnace slag", Minerals Engineering, 16 (2003), pp. 205-210. http: //dx. doi. org/10. 1016/S0892-6875(03)00008-6

(16) Guerrieri, M.; Sanjayan, J.; Collins, F.: "Residual compressive behavior of alkali-activated concrete exposed to elevated temperatures", Fire and Materials, 33 (2009), pp. 51-62. http: //dx. doi. org/10. 1002/fam. 983

(17) Zuda, L.; Drchalová, J.; Rovnaník, P.; Bayer, P.; Keršner, Z.; Černý, R.: "Alkali-activated aluminosilicate composite with heatresistant lightweight aggregates exposed to high temperatures: Mechanical and water transport properties", Cem. Concr. Comp., 32 (2010), pp. 157-163. http: //dx. doi. org/10. 1016/j. cemconcomp. 2009. 11. 009

(18) Puertas, F.; Gil-Maroto, A.; Palacios, M.; Amat, T.: "Alkali-activated slag mortars reinforced with AR glassfibre. Performance and properties", Mater. Construcc., 56 (2006), pp. 79-90.

(19) Mejía de Gutiérrez, R.; Maldonado, J.; Gutiérrez, C.: "Resistencia a temperaturas elevadas de escoria activadas alcalinamente", Mater. Construcc., 54 (2004), pp. 87-92.

(20) Duxson, P.; Provis, J. L.; Lukey, G. C.; Mallicoat, S. W.; Kriven, W. M.; van Deventer, J. S. J.: "Understanding the relationship between geopolymer composition, microstructure and mechanical properties", Colloids and Surfaces A - Physicochemical and Engineering Aspects, 269 (2005), pp. 47-58. http: //dx. doi. org/10. 1016/j. colsurfa. 2005. 06. 060

(21) Bernal, S. A.; Mejía de Gutiérrez, R.; Rose, V.; Provis, J. L.: "Effect of silicate modulus and metakaolin incorporation on the carbonation of alkali silicate-activated slags", Cem. Concr. Res., 40 (2010), pp. 898-907. http: //dx. doi. org/10. 1016/j. cemconres. 2010. 02. 003

(22) Hewlett, P. C.: Lea's Chemistry of Cement and Concrete, 4th Ed., Elsevier, Oxford, UK, 1998.

(23) Van Riessen, A.; Rickard, W.; Sanjayan, J.: "Thermal properties of geopolymers", in: J. L. Provis, J. S. J. van Deventer (eds.), Geopolymers: Structures, Processing, Properties and Industrial Applications, Woodhead, Cambridge, UK, 2009, pp. 317-344.

(24) Bernal, S. A.; Mejia de Gutiérrez, R.; Provis, J. L.: "Engineering and durability properties of concretes based on alkali-activated granulated blast furnace slag/metakaolin blends", Constr. Build. Mater., 33 (2012), pp. 99-108. http: //dx. doi. org/10. 1016/j. conbuildmat. 2012. 01. 017 
(25) Rodríguez, E.; Mejía de Gutiérrez, R.; Bernal, S.; Gordillo, M.: "Effect of the SiO2/Al2O3 and Na2O/SiO2 ratios on the properties of geopoly merbasedon MK, Revista de la Facultad de Ingeniería de la Universidad de Antioquia, 49 (2009), pp. 30-40.

(26) Bernal, S. A.; Mejía de Gutiérrez, R.; Pedraza, A. L.; Provis, J. L.; Rodríguez, E. D.; Delvasto, S.: "Effect of binder content on the performance of alkali-activated slag concretes", Cem. Concr. Res., 41 (2011), pp. 1-8. http: //dx. doi. org/10. 1016/j. cemconres. 2010. 08. 017

(27) Yip, C. K.; Lukey, G. C.; van Deventer, J. S. J.: "The coexistence of geopolymeric gel and calcium silicate hydrate at the early stage of alkaline activation", Cem. Concr. Res., 35 (2005), pp. 1688-1697. http: //dx. doi. org/10. 1016/j. cemconres. 2004. 10. 042

(28) Buchwald, A.; Hilbig, H.; Kaps, C.: "Alkali-activated metakaolin-slag blends - Performance and structure in dependence on their composition", Journal of Materials Science, 42 (2007), pp. 3024-3032. http: //dx. doi. org/10. 1007/s10853-006-0525-6

(29) García Lodeiro, I.; Fernández-Jiménez, A.; Palomo, A.; Macphee, D. E.: "Effect on fresh C-S-H gels of the simultaneous addition of alkali and aluminium", Cem. Concr. Res., 40 (2010), pp. 27-32. http: //dx. doi. org/10. 1016/j. cemconres. 2009. 08.004

(30) Provis, J. L.; Myers, R. J.; White, C. E.; Rose, V.; van Deventer, J. S. J.: "X-ray microtomography shows pore structure and tortuosity in alkali-activated binders", Cem. Concr. Res., (2012) DOI: 10. 1016/j. cemconres. 2012. 1003. 1004. http: //dx. doi. org/10. 1016/j. cemconres. 2012. 1003. 1004

(31) Duxson, P.; Lukey, G. C.; Separovic, F.; van Deventer, J. S. J.: "The effect of alkali cations on aluminum incorporation in geopolymeric gels", Industrial \& Engineering Chemistry Research, 44 (2005), pp. 832-839. http: //dx. doi. org/10. 1021/ie0494216

(32) Duxson, P.; Lukey, G. C.; van Deventer, J. S. J.: "The thermal evolution of metakaolin geopolymers: Part 2 - Phase stability and structural development", Journal of Non-Crystalline Solids, 353 (2007), pp. 2186-2200. http: //dx. doi. org/10. 1016/j. jnoncrysol. 2007. 02. 050

(33) Rowles, M.; O'Connor, B.: "Chemical optimisation of the compressive strength of aluminosilicate geopolymers synthesised by sodium silicate activation of metakaolinite", Journal of Materials Chemistry, 13 (2003), pp. 1161-1165. http: //dx. doi. org/10. 1039/b212629j

(34) Welche, P. R. L.; Heine, V.; Dove, T.: "Negative thermal expansion in beta-quartz", Phy Chem Miner, 26 (1998), pp. 63-77. http: //dx. doi. org/10. 1007/s002690050161

(35) Halpál, M.; Török, Á.: "Mineralogical and colour change of quartz sandstones by heat", Environmental Geology, 46 (2004), pp. 311322.

(36) Zuda, L.; Černý, R.: "Measurement of linear thermal expansion coefficient of alkali-activated aluminosilicate composites up to $1000{ }^{\circ} \mathrm{C}$ ", Cem. Concr. Comp., 31 (2009), pp. 263-267. http: //dx. doi. org/10. 1016/j. cemconcomp. 2009. 02. 002

(37) Rickard, W. D. A.; van Riessen, A.; Walls, P.: "Thermal character of geopolymers synthesized from Class F fly ash containing high concentrations of iron and $\alpha$-quartz", International Journal of Applied Ceramic Technology, 7 (2010), pp. 81-88. http: //dx. doi. org/10. 1111/j. 1744-7402. 2008. 02328. x

(38) White, C. E.; Provis, J. L.; Proffen, T.; Riley, D. P.; van Deventer, J. S. J.: "Density functional modeling of the local structure of kaolinite subjected to thermal dehydroxylation", Journal of Physical Chemistry A, 114 (2010), pp. 4988-4996. http: //dx. doi. org/10. 1021/jp911108dPMid: 20297842

(39) Alarcon-Ruiz, L.; Platret, G.; Massieu, E.; Ehrlacher, A.: "The use of thermal analysis in assessing the effect of temperature on a cement paste", Cem. Concr. Res., 35 (2005), pp. 609-613. http: //dx. doi. org/10. 1016/j. cemconres. 2004. 06. 015

(40) Fernández-Jiménez, A.; Puertas, F.: "Structure of calcium silicate hydrates formed in alkaline-activated slag: Influence of the type of alkaline activator", Journal of the American Ceramic Society, 86 (2003), pp. 1389-1394. http: //dx. doi. org/10. 1111/j. 1151-2916. 2003. tb03481. $x$

(41) Bernal, S. A.; Provis, J. L.; Mejía de Gutiérrez, R.; Rose, V.: "Evolution of binder structure in sodium silicate-activated slagmetakaolin blends", Cem. Concr. Comp., 33 (2011), pp. 46-54. http: //dx. doi. org/10. 1016/j. cemconcomp. 2010. 09. 004

(42) Wang, S. D.; Scrivener, K. L.: "Hydration products of alkali-activated slag cement", Cem. Concr. Res., 25 (1995), pp. 561-571. http: //dx. doi. org/10. 1016/0008-8846(95)00045-E

(43) Chan, Y. N.; Luo, X.; Sun, W.: "Compressive strength and pore structure of high-performance concrete after exposure to high temperature up to $800^{\circ} \mathrm{C}^{\prime \prime}$, Cem. Concr. Res., 30 (2000), pp. 247-251. http: //dx. doi. org/10. 1016/S0008-8846(99)00240-9

(44) Duxson, P.; Lukey, G. C.; van Deventer, J. S. J.: "Evolution of gel structure during thermal processing of Na-geopolymer gels", Langmuir, 22 (2006), pp. 8750-8757. http: //dx. doi. org/10. 1021/la0604026PMid: 17014113.

(45) Duxson, P.; Lukey, G. C.; van Deventer, J. S. J.: "Physical evolution of Na-geopolymer derived from metakaolin up to $1000{ }^{\circ} \mathrm{C}$ ", Journal of Materials Science, 42 (2007), pp. 3044- 3054. http: //dx. doi. org/10. 1007/s10853-006-0535-4 